\title{
FIRM EFFICIENCY: DOMESTIC OWNERS, COALITIONS, AND FDI
}

\author{
Jan Hanousek \\ Evžen Kočenda \\ Michal Mašika
}
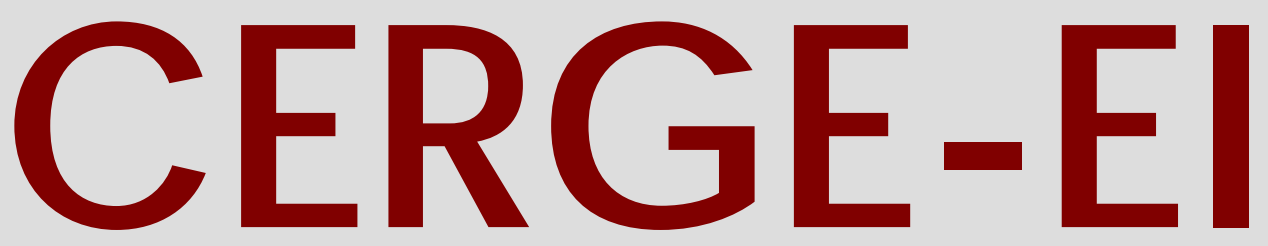

Cha rles University Centerfor Economic Research and Graduate Education Academy of Sciences of the Czech Republic Ec onomic s Institute 


\title{
Working Paper Series 456 (ISSN 1211-3298)
}

\section{Firm Efficiency: \\ Domestic Owners, Coalitions, and FDI}

\author{
Jan Hanousek \\ Evžen Kočenda \\ Michal Mašika
}

CERGE-EI

Prague, April 2012 
ISBN 978-80-7343-259-1 (Univerzita Karlova. Centrum pro ekonomický výzkum a doktorské studium)

ISBN 978-80-7344-251-4 (Národohospodářský ústav AV ČR, v.v.i.) 


\title{
Firm Efficiency: Domestic Owners, Coalitions, and FDI
}

\author{
Jan Hanousek, Evžen Kočenda, ${ }^{* *}$ and Michal Mašika ${ }^{* * *}$
}

\begin{abstract}
In this paper we analyze the evolution of firm efficiency in the Czech Republic. Using a large panel of more than 190,000 Czech firm/years we study whether firms fully utilize their resources, how firm efficiency evolves over time, and how firm efficiency is determined by ownership structure. We employ a panel version of a stochastic production frontier model for the period 1996-2007 with time-varying efficiency. We differentiate among various degrees of ownership concentration and domestic or foreign origin. In a two-stage set-up we estimate the degree of firm inefficiency and then we estimate the effect of ownership structure on the distance from the efficiency frontier. Our results support the hypothesis that concentration and foreign ownership are positively related to efficiency and that FDI has beneficial effects at the microeconomic level. However, we show that a simple majority is not necessarily the best structure to improve efficiency. We further analyze the effects of ownership coalitions, and shed light on many other subtleties of how ownership and the specific industry affect firm efficiency.
\end{abstract}

Keywords: efficiency, ownership structure, firms, panel data, stochastic frontier JEL Classification: C33, D24, G32, L60, L80, M21

* CERGE-EI, is a joint workplace of the Center for Economic Research and Graduate Education, Charles University, and the Economics Institute of Academy of Sciences of the Czech Republic. Address: CERGE-EI, P.O. Box 882, Politických vězňů 7, Prague 1, 111 21, Czech Republic; Anglo-American University, Prague; The William Davidson Institute, Michigan; and CEPR, London. CERGE-EI, Charles University, Academy of Sciences, Politickych veznu 7, P.O.Box 882, 11121 Prague, Czech Republic. tel. (+420) 224.005.119 fax: (+420) 224.005.444 E-mail: jan.hanousek@cerge-ei.cz.

** Corresponding author. CERGE-EI, Charles University and the Academy of Sciences, Prague; AngloAmerican University, Prague; CESifo, Munich; OEI, Regensburg; The William Davidson Institute, Michigan; CEPR, London; and the Euro Area Business Cycle Network. CERGE-EI, Charles University, Academy of Sciences, Politickych veznu 7, P.O.Box 882, 11121 Prague, Czech Republic. tel. (+420) 224.005.149, 224.005.153 fax: (+420) 224.005.333 E-mail: evzen.kocenda@cerge-ei.cz.

*** Ludwig-Maximilians-Universität, München. Munich Graduate School of Economics, Seminar for Comparative Economics, Department of Economics, Akademiestr.1 /III, 80799 Munich, Germany. Tel.: +49 89 2180 6782, Fax: +49 8921802767 E-mail: michal.masika@lrz.uni-muenchen.de.

Part of this paper was written while Evžen Kočenda was a Visiting Fellow at the Institute of East and Southeast European Studies (WiOS), Regensburg, whose hospitality is greatly appreciated. We are thankful for valuable comments from Richard Frensch, Stephan Huber, Henry Hyatt, Jürgen Jerger, Lubomír Lízal, Dieter Sadowski, Laurent Weill, and Krešimir Žigić. Support from GAČR grant No. 403/12/0080 is gratefully acknowledged. The usual disclaimer applies. 


\begin{abstract}
Abstrakt
V tomto článku analyzujeme vývoj podnikové efektivity v České Republice. Za použití rozsáhlého panelu dat s více než 190000 pozorováními na podnik a rok v období 1996-2007 se zábýváme otázkami zda firmy plně využívají své zdroje, jak se vyvíjí jejich efektivita $\mathrm{v}$ čase, a jak je podniková efektivita ovlivněna vlastnickou strukturou. Metodologicky pracujeme s panelovou verzí modelu stochastické produkční hranice s efektivitou měnící se v čase. Rozlišujeme různé úrovně vlastnické koncentrace a domácí či zahraniční původ vlastníků. Ve dvoustupňovém modelu odhadujeme rozsah podnikové efektivity a poté odhadujeme vliv vlastnické struktury na vzdálenost hranice efektivity. Naš výsledky podporují hypotézu, že koncentrované a zahraniční vlastnictví jsou kladně provázány s efektivitou a že prrímé zahraniční investice vykazují kladné vlivy na mikroekonomické úrovni. Ukazujeme však také, že prosté většinové vlastnictví není nutně tou nejlepší strukturou pro lepší efektivitu. Dále analyzujeme vlivy vlastnických koalic a osvětlujeme mnohé detaily o vlivu vlastnicví a konkrétních ekonomických sektorů na podnikovou efektivitu.
\end{abstract}




\section{Introduction}

The economic reforms of the 1990s in Central and Eastern Europe (CEE) were aimed at creating competitive market economies and more efficient enterprises by firm restructuring, privatization, and supporting institutional reforms (Aussenegg and Jelic, 2007). In this respect, it became evident that ownership type was a key determinant of corporate performance in CEE countries (Estrin et al., 2009). In terms of firm efficiency, the lack of reliable empirical evidence precludes an assessment of firm efficiency and its determinants in the CEE countries (Hanousek et al., 2007a). We make a topical contribution to the literature by analyzing the efficiency of Czech firms and how this efficiency is determined by ownership structures. We employ a stochastic production frontier model and use unique firmlevel panel data of more than 190,000 firm/year observations for the period 1996-2007. Our results are in line with the theoretical predictions that concentration and foreign ownership are positively related to efficiency in general (Hill and Snell, 1989; Blomström et al., 2001). However, we show that a simple majority is not necessarily the best structure to improve efficiency. We further analyze the effects of ownership coalitions and shed light on many other subtleties of how ownership and the specific industry affect firm efficiency.

In our research we analyze two kinds of firms: privatized formerly state-owned enterprises (SOEs) and newly established firms. The privatization of the SOEs in the former command economies in Central and Eastern Europe has been at the center of a debate among economists and policy makers since the late 1980s. The SOEs were originally established to ensure a better provision of public goods as well as political control of production in centrally planned economies. However, they were not able to keep up with technical and innovative progress. For this reason both economists and policy makers expected SOEs' efficiency to increase after privatization under new owners and management but institutional, legal, and accounting deficiencies hampered performance in many privatized firms (Jandik and Rennie, 2008). Finally, newly established firms, either having domestic owners but often in the form of Foreign Direct Investment (FDI), were expected to exhibit high performance as they were established by new owners with a focus on core competence and profits. Particular emphasis was placed on FDI to increase the competitiveness and productivity of the domestic industry (Javorcik, 2004).

Our paper is therefore related to two strands of literature. First, we contribute to the literature examining the effects of ownership type and ownership structure on firm performance in transition countries (see Boycko et al., 1996 for a theoretical treatment and Estrin et al., 2009 for empirical surveys). The actual literature almost uniformly suggests that 
privatization to foreign owners improves performance. The positive effect of FDI on firm performance is specifically reported by Djankov and Hoekman (2000) for Czech firms, by Javorcik (2004) for Lithuania, and Sabirianova et al. (2005b) for Czech and Russian firms. The effect of domestic ownership is largely also positive but not as positive as the effect of foreign ownership. In terms of the ownership concentration, several studies examine the concentration of ownership and find that it plays an important role, with majority private ownership having mostly positive effects on productivity (Pivovarsky, 2003; Claessens and Djankov, 1999; Hanousek et al., 2007a). The overall positive effect is again driven primarily by foreign-owned firms. Finally, some studies suggest that de novo firms are more productive than, or at least as productive as, SOEs privatized to domestic owners (Sabirianova et al., 2005a). In contrast to the above review on firm performance, the literature on firm efficiency in CEE countries is rather limited.

Second, our paper is related to the literature estimating technical efficiency. We employ the stochastic production possibility frontier approach introduced by Aigner et al. (1977) and Meeusen and van den Broeck (1977) and further adapted for panel data and timevarying technical efficiency by Khumbhakar (1990) and Battese and Coelli (1995). Although this methodology is well established in the empirical literature, there is still a lack of reliable empirical evidence on firm technical efficiency in post-transition economies. A few authors analyze this agenda for the pre-transition years and early transition years, finding that there is substantial variation between highly efficient firms and firms that can still achieve considerable efficiency gains (for Poland, Brada and King, 1994; for Czechoslovakia and Hungary, Brada et al., 1994). Further, Konings and Repkin (1998) estimated the efficiency of firms in Bulgaria (1993-1995) and Romania (1994-1995), showing that technical efficiency varies significantly both within and across industrial sectors in each country. Sabirianova et al. (2005b) investigate whether Czech and Russian firms near the efficiency frontier benefit from implementing development policies but the authors estimate the average efficiency level rather than the individual levels and their specification contains only simple categories of ownership.

Studies targeting the early stage of the transformation frequently use small and often unrepresentative samples of firms, often combine data from different accounting systems, and have access to limited data on firm ownership. As a result, they often treat ownership as a relatively simple categorical concept (e.g., private versus state, state versus foreign, domestic private outsider versus domestic private insider), and they are often unable to distinguish the exact extent of ownership by individual owners or even relatively homogeneous groups of 
owners. These shortcomings prevent many studies from providing accurate evidence on the effects of various ownership categories on technical efficiency.

In this paper we advance the literature by systematically addressing issues related to the efficiency effects of ownership and by eliminating the earlier shortcomings. First, we use panel data on a large sample of medium and large firms in the Czech Republic that were privatized $^{1}$ as well as those established as new firms; they constitute the bulk of the country's economic activity. Second, we cover a period when accounting rules conforming to the international standard (IAP) were already in place. Third, we develop a more systematic analytical framework for evaluating the efficiency effect of domestic versus foreign ownership, as well as the effect of various degrees of ownership concentration. Fourth, we employ a methodology that overcomes the potential problem of unobserved (fixed) firm heterogeneity, including the endogeneity of firm ownership with respect to efficiency.

The paper is structured as follows. In Section 2 we present our methodological approach. The data is described in Section 3. Section 4 presents our empirical results and section 5 concludes.

\section{Modeling Strategy}

\subsection{Theoretical background}

In our analysis we employ the stochastic production possibility frontier approach introduced by Aigner et al. (1977) and Meeusen and van den Broeck (1977) and further adapted for panel data by Khumbhakar (1990) and Battese and Coelli (1995). The method measures technical inefficiency under single-output production. More important, the methodology helps to explain firm-level differences in efficiency as a function of the number of explanatory variables as opposed to estimating the average efficiency relative to the "best practice" for a number of sectors.

The methodology of the stochastic frontier approach is developed in the following way. A firm has the production function

$$
y_{i}=f\left(x_{i} ; \beta\right)
$$

\footnotetext{
${ }^{1}$ A massive privatization program was administered in the Czech Republic in the first half of the 1990s under three different schemes: restitution, small-scale privatization, and large-scale privatization. The first two schemes began in 1990 and were important during the early years of the transition. Large-scale privatization, by far the most important scheme, began in 1991, was completed in early 1995, and allowed for various privatization techniques (auctions, tenders, direct sales, and free transfers). Most large-size and many medium-size firms were transformed into joint-stock companies and their shares were distributed through voucher privatization (almost one-half of the total number of all of the shares of all joint stock companies were privatized in the voucher scheme), sold in public auctions or to strategic partners, or transferred to municipalities. The voucher scheme was part of the large-scale privatization process. Two waves of voucher privatization took place, in 1992-93 and 1993-94. Both waves were administered in the same manner and there were no differences in their set-up. During the scheme, a total of 1664 firms were privatized.
} 
that defines the technological link between inputs $(x)$ and the resulting output $(y)$ under the assumption that production is conducted in an efficient manner. Due to some degree of inefficiency, a firm potentially produces less than it might and its production function is

$$
y_{i}=f\left(x_{i} ; \beta\right) \cdot T E_{i} .
$$

The firm's technical efficiency $T E_{i}$ represents the ratio of observed output to maximum feasible output and lies within the interval $(0,1] ; T E_{i}$ is considered to be nonnegative since the firm's output is assumed to be positive. If $T E_{i}=1$ then the firm employs all inputs efficiently and achieves an optimal output. If $T E_{i}$ is smaller than one then the firm experiences a degree of inefficiency in its production. Further, two assumptions are made. One, efficiency is a stochastic variable with a distribution common to all firms and can be written as $T E_{i}=\exp \{-$ $\left.u_{i t}\right\}$; since if $0<T E_{i} \leq 1$, then $u_{i t} \geq 0$. Two, the firm's output is also subject to various random shocks that encompass anything from bad weather to unexpected luck and these effects are denoted as $\exp \left(v_{i t}\right)$. Thus, the production function is further expanded to

$$
y_{i}=f\left(x_{i} ; \beta\right) \cdot \exp \left(-u_{i t}\right) \cdot \exp \left(v_{i t}\right) .
$$

After taking the natural log of both sides we obtain

$$
\ln y_{i t}=\beta_{0}+\sum_{j=1}^{k} \beta_{j i t} \ln x_{i t}+v_{i t}-u_{i t} .
$$

In this general specification $v_{i t}$ is a pure noise component and a two-sided normally distributed variable, while $u_{i t}$ is the nonnegative technical inefficiency component. Both terms form a compound error term with an a priori unknown distribution. The model is estimated by maximum likelihood assuming a log-quadratic production function that encompasses the Cobb-Douglas specification and represents a less restrictive production function.

\subsection{Empirical approach - Efficiency}

In order to assess the determinants of firm efficiency we first employ a Cobb-Douglas function to model firm output. The Cobb-Douglas production function is a convenient tool that is directly connected to the theoretical approach outlined earlier. From the empirical perspective Hájková and Hurník (2007) show that there is no significant difference between the total factor productivity growth estimated for Czech firms by Cobb-Douglas and by a more general production function. Moreover, quite a few authors examining the transformation effects in CEE and CIS countries argue that the Cobb-Douglas specification cannot be rejected (e.g., Brown et al., 2006 and Brada et al., 1994).

The Cobb-Douglas function assumes that input elasticities and returns to scale are constant, and that the elasticities of substitution are equal to one. From the empirical 
perspective both assumptions are linked to the evidence that industries within a one-digit NACE division differ with respect to capital intensity, labor intensity, or technology intensity (Bjørnskovetal., 2009; Laafia, 2002). Therefore, we follow the mainstream of the literature and consider the interacting parameters of the Cobb-Douglas production function with twodigit NACE industry divisions. As a result, in the specification below we consider different parameters of the Cobb-Douglas function for each two-digit NACE sector and this way we account for the specifics of a given sector. Formally, our model of the efficiency frontier of $i$ firms $(i=1, \ldots, I)$ in $J$ two-digit NACE sectors $(j=1, \ldots, J)$ over $T$ time periods $(t=1, \ldots, t)$ is specified as follows:

$\ln y_{i t}=\sum_{j=1 \ldots J}\left[\beta_{0 j}+\beta_{1 j} \ln c_{i t}+\beta_{2 j} \ln l_{i t}\right] \cdot I D_{i t j}+\phi_{t}+v_{i t}-u_{i t}$.

In specification (2) $\ln y_{i t}$ is the natural $\log$ of the value of the production of firm $i$ at time $t$, measured as firm sales. Then $\ln c_{i t}$ is the natural $\log$ of the capital of each firm measured as working capital, and $\ln l_{i t}$ is the natural $\log$ of the firm's labor, measured as the number of employees. A common intercept for all firms is denoted by $\beta_{0}$. Working capital is the optimal proxy for capital in our efficiency analysis. It is true that the money tied up in working capital is costly since it earns zero rate of return (Kim et al., 1998). However, managing working capital efficiently stimulates growth opportunities and enables avoiding costly interruptions to firms' day-to-day operations (Ross et al., 2005). Hence, working capital is kept invested constantly with the purpose to secure the constant production of the firm, which is directly linked to its efficiency. A firm's capital can be understood as a proxy for the machinery used in production as input while the number of employees directly measures labor input. ${ }^{2}$

$I D_{i j t}$ represents a vector of dummy variables to associate each firm with the specific industry sector $j$ it operates in. By the construction of the model we interact dummy variables for each of the 45 two-digit NACE industries with both inputs (capital and labor) to control for industry-specific effects. In addition, we divide these industry sectors into six basic groups based on the different degrees of technology and knowledge intensity they represent (see Section 3 for details).

Further, it has been shown that ownership structures in firms are often industryspecific (see e.g., Demsetz, 1983 and Demsetz and Lehn, 1985 for theoretical evidence and Thomsen and Pedersen, 1998 for empirical evidence). Therefore, we employ industry-sector dummies in the first stage to capture the specific effects of various sectors so that these effects do not interfere with the ownership effects in the second stage. For the same reason we also

\footnotetext{
${ }^{2}$ During estimation we employed different measures of capital as well as staff costs. Our results were not materially different. All alternative results are readily available upon request.
} 
include in specification (2) yearly time dummies $\left(\phi_{t}\right)$ that control for time-specific effects (country-wide economic development and business cycles) that are equal for all firms but vary over time. Finally, the random error is denoted as $v_{i t}$ as in (1) and $u_{i t} \geq 0$ represents inefficiency. Producer effects are required to be nonnegative because they represent the degree of inefficiency.

Specification (2) is based on the assumption that production technology changes over time as in the time-varying technical efficiency stochastic production frontier panel data model proposed by Cornwell et al. (1990), Kumbhakar (1990), and Battese and Coelli (1995). Inefficiency is formalized as $u_{i t}=\exp \left(-\eta\left(t-T_{i}\right)\right) u_{i}$, where $T_{i}$ is the last period in the panel of $i$ firms. Parameter eta $(\eta)$ enables distinguishing whether the efficiency increases or decreases over time. If $\eta>0$, the firm's efficiency increases over time, while efficiency decays if $\eta<0 .{ }^{3}$ Because $t=T_{i}$ in the last period, the last period for firm $i$ contains the base level of inefficiency for that firm. If $\eta>0$, the level of efficiency increases toward the base level, and if $\eta<0$, the level of efficiency decays toward the base level. Finally, $u_{i}$ is iid-distributed $(\sim)$ according to a truncated-normal distribution that is truncated at zero with mean $\mu$ and variance $\sigma_{\mathrm{u}}^{2}\left(u_{i} \sim \mathrm{N}^{+}\left(\mu, \sigma_{u}^{2}\right)\right.$. The random error $v_{i t}$ is iid-distributed as $v_{i t} \sim \mathrm{N}\left(0, \sigma^{2}{ }_{v}\right)$. Then $u_{i}$ and $v_{i t}$ are distributed independently from each other as well as from the covariates in the model.

The above approach allows for efficiency to be influenced by factors outside the firm's control. We can distinguish random shocks that affect the production frontier (machinery breakdown, new policies affecting access to or utilization of inputs, etc.) from factors over which the firm has some control (workforce size, skill and effort, capital utilization, etc). The specification itself is estimated as a panel with fixed effects to alleviate the potential problem of unobserved (fixed) firm heterogeneity, including the endogeneity of firm ownership with respect to efficiency.

\subsection{Empirical approach-Determinants of efficiency}

Ownership structures have been identified in numerous relevant studies as a key determinant of firm performance (see Estrin et al., 2009 for a general overview and Hanousek et al., 2007a, 2009 for specific results related to Czech firms). Therefore, we model how firm efficiency $\left(u_{i}\right)$ is determined by a firm's ownership structure: $\left(u_{i}\right)=f$ (ownership structure); a formal model is introduced later in this section. Specifically, we aim to answer the questions below, formulated as hypotheses.

\footnotetext{
${ }^{3}$ If there are no changes in technology, (in)efficiency remains the same over time $(\eta=0)$ and the time-varying model reduces to the time-invariant version. During the estimation we formally test for the correct specification and based on the test results that show a visible decay we employ the time-varying efficiency model.
} 
The literature examining the agency problem arising from the separation of ownership and control often argues that managers might follow other goals than the owners would like. Because of this, a concentrated ownership structure might lead to higher firm efficiency since it results in the superior monitoring of managers (Shleifer and Vishny, 1997; Hill and Snell, 1989). Therefore, we expect that there will be a positive relationship between ownership concentration and efficiency. As pointed out above we are able to identify all owners with ownership stakes of at least 10 percent; sometimes, but definitely not as a rule, we are able to identify dispersed ownership of less than $10 \%$. Therefore, we are able to test whether the baseline relationship between ownership concentration and efficiency holds and formulate a baseline hypothesis:

Hypothesis 1: A majority owner reduces a firm's inefficiency.

Empirical works show that majority owners can change their attitude when a strong minority owner is present in the firm, for example in the case of dividend payments (Gugler, 2003). We speculate that a majority owner, when confronted with a strong minority owner, might affect a firm's efficiency. This leads to our second hypothesis:

Hypothesis 2: A majority owner confronted with strong minority owner(s) (monitored majority ownership, see below) reduces a firm's inefficiency.

The findings of agency theory indicate that control is a very good mechanism to assure that managers work to help owners. In other words, dispersed and/or minority ownership should not improve a firm's efficiency as control is very likely to be missing in such an ownership structure. On the other hand, in the presence of dispersed ownership, even a minority owner with a sufficiently high stake is able to control a firm; for example, La Porta et al. (1999) employ $20 \%$ as a threshold for control of a company. Control can be exerted to ensure that managers fulfill their duties. Our data allows us to test the link between control and efficiency as we are able to identify dispersed ownership as well as controlling minority ownership. Based on this reasoning we formulate the next two hypotheses.

Hypothesis 3: Minority controlling ownership reduces a firm's inefficiency.

Further, in the trade literature it has been argued that foreign owners have better access to technology and therefore multinational firms established through FDI and owned by foreign owners should be more efficient (Temouri et al., 2008; Blomström et al., 2001). The existence of the technological gap between foreign and domestic owners has become a stylized fact in the applied trade literature. Specifically in the European context, Mathur et al. (2004) show that foreign-owned firms involved in multinational operations do better in financial performance than purely domestic units. Based on the evidence related to FDI ownership we formulate the next hypothesis: 
Hypothesis 4: A foreign owner (through FDI) reduces a firm's inefficiency.

We aim to test the above hypotheses by employing a model that links firm efficiency with its ownership structure plus some other key firm characteristics. The model for each year (period $t$ ) is specified as follows:

$$
u_{i t}=\alpha+\sum_{j=1}^{J} \delta_{j} O W N_{i t}^{j}+\beta_{1} \text { Size }+\beta_{2} \text { Debt }+\beta_{3} \text { Age } \quad \text { for all } i=1, \ldots \mathrm{N} \text { and } \mathrm{t}=1, . ., \mathrm{T} \text {. }
$$

In specification (3) the ownership structure $\left(O W N_{i t}{ }^{j}\right)$ is defined in year $t$ for each firm $i$ to account for a specific ownership category $j$. We distinguish the domestic or foreign ownership of private firms based on the exact knowledge of the owner's origin. If there is missing information on the owner's domicile we introduce a special category of "unknown" domicile. Therefore, we consider the categories of domestic, foreign, and unknown domicile owners. From our data we can also distinguish the extent of the ownership concentration along with the extent of control over a firm. Following the country- and legal-specific approach of Hanousek et al. (2007a), we construct ownership categories to distinguish majority (stake above 50\%), monitored majority, minority (stake above 33\%), and controlling minority ownership. We elaborate more on the ownership categories in the data section. By the construction of specification (3), positive coefficients associated with specific ownership categories mean that under that ownership control the firm moves further from the efficiency frontier. Hence, a larger positive coefficient means that under that specific type of ownership a firm is less efficient. On the contrary, a negative sign illustrates the fact that a firm gets closer to the efficiency frontier.

Further, we include several variables that represent major firm characteristics. Size, measured as $\log$ (Total Assets), captures the effect of firm size on inefficiency; in this respect we are able to test the hypothesis that larger firms are less efficient, a feature depicted by a positive coefficient. Debt is defined as Current Liabilities/Total Assets (in percent) and accounts for the effect of firm capital structure on efficiency. We are therefore able to test the hypothesis whether more indebted firms are more efficient, a feature depicted by a negative coefficient. Finally, Age is defined as the number of years from a firm's incorporation and measures the effect of a firm's age on efficiency. ${ }^{4}$ By including a firm's age we are able to test the hypothesis that older firms are more efficient, a feature depicted by a negative sign.

Specification (3) recognizes that ownership structure affects firm efficiency. In the trade literature it is usually argued that only very productive firms are able to be internationally active (Melitz, 2003). As the foreign-owned firms have a knowledge advantage

\footnotetext{
${ }^{4}$ We acknowledge that the age variable could also capture the effect of survival bias. However, given that firms are leaving as well as entering the panel data set based on factors under the control of the data collecting agency (Amadeus), we consider this possibility negligible.
} 
they are able to increase their efficiency via spillovers. Moreover, it is likely that foreign owners have more experience in the business environment as well as better access to superior technologies (Temouri et al., 2008). This can result in better efficiency. Another explanation of the productivity gap between foreign- and domestic-owned firms could be differential access to external credit (Gorodnichenko and Schnitzer, 2010). This reason is largely absent in the case of the Czech Republic, though. Access to external financing was relatively easy before banks were fully privatized and banking privatization was achieved by 2001 (Hanousek at al., 2007b). After EU accession in 2004 the frictions on the lending market were largely absent as the country complied with acquis communautaire.

Finally, the distinction between domestic and foreign ownership represents an important implication with respect to FDI. From our data we are able to distinguish specific ownership stakes of $10 \%$ and up. Based on the official definition if a direct investor "owns equity that entitles it to 10 percent or more of the voting power" (IMF 2009; p. 101) or "the direct investor owns at least $10 \%$ of the voting power" (OECD 2008; p. 17) in a firm, then the firm is considered a direct investment and the foreign domicile of the direct investor constitutes the FDI. Hence, based on our data, majority and minority control categories provide information about FDI ownership and we can analyze its impact on a firm's efficiency.

\subsection{Estimation technology}

For clarity of exposition we divided description of the efficiency and its determinants into two sub-sections above as the estimated model consists of two equations: specification (2) describes efficiency frontier and specification (3) models determinants of the efficiency. The model is estimated using maximum likelihood one-stage procedure designed by Battese and Coelli (1995). We obtain estimates of the efficiency frontier parameters as well as estimates of the efficiency determinants. Our estimation is performed in a similar manner as that of Weill (2008) and the procedure delivers efficient estimates that are free of potential correlation among variables.

\section{Data}

We develop a model to examine the impact of ownership structure on firm efficiency in the Czech Republic. We employ firm-level unbalanced panel data for the period 1998-2007 from the Amadeus database, and depending on the specific year, we have firm-level balance-sheet data (sales, working capital, and number of employees) for 4240 to 34,642 firms. As these are multiproduct firms we are unable to obtain exact information about the quantities (input, 
output) connected with the production process of each product of a firm. For this reason we follow the standard approach in the literature and employ the financial variables from firms' balance sheets (see Coelli et al., 2005 for an overview). We further combine the balance-sheet data with ownership data obtained from the Amadeus, Aspekt, and Čekia databases. Altogether we work with unique firm-level panel data of more than 190,000 firm/year observations for the period 1998-2007.

The descriptive statistics for all of the variables are presented in Table 1. The number of firms increases dramatically from 1998 on, confirming our argument in Section 1 that early studies relying on unrepresentative samples could not deliver accurate results. Further, since our data set is constructed from several editions of the Amadeus database, we include in our data set also firms that might disappear from more recent editions. This way we minimize the selection and survival biases. The mean values of our economic variables are in absolute values to provide a perspective on the scope of operation. As can be seen from the values of the mean of working capital as well as the number of employees, more and more of the smaller firms enter our data set as time progresses. This is in accord with the values for sales, which decrease with time as well.

We derive firm efficiency based on the two-input (capital, labor) Cobb-Douglas production specification introduced in Section 2. We use sales to measure the production of each firm and as inputs we employ working capital (which is a major part of current assets, represented by stocks+debts-credits) and number of employees. ${ }^{5}$ The variables are in natural logs as shown in specification (2) to minimize the effect of different firm size. In specification (2) we also include annual time dummy variables serving as a deflator of our financial variables in the same manner as in Sabirianova et al. (2005a): after taking the logarithm of the nominal values the price effect is captured by the annual dummies. As firm efficiency might be industry-specific (Pavitt, 1984), we include industry sectors as explanatory variables as well. Industry sectors are identified according to the two-digit NACE category. In order to capture different effects across sector-specific intensities we follow the approach of Laafia (2002), who divides industries into different sectors based on their technology and knowledge intensity. This approach is based on the official Eurostat industrial-sector aggregations. Hence, following the official Eurostat methodology we define several groups of industries in

\footnotetext{
${ }^{5}$ In order to show that our results are robust to the use of different input proxies we estimate the Cobb-Douglas function with total assets, fixed assets, and total capital as proxies for capital and staff costs as a proxy for labor. Note that staff costs and number of employees are close measures of labor intensity since within a given industrial sector we can expect a relatively stable wage distribution as shown by Krueger and Summers (1988) as well as Crinò (2005) specifically for Poland, Hungary, and the Czech Republic. Additional definitions and relationships between financial variables used can be found at http://amadeus.bvdep.com/amadeus/help/HelpAmadeus/AFAccRat.htm.
} 
manufacturing and services to reflect the different degrees of technology and knowledge they represent. In manufacturing industries we have four groups: high technology, medium-high technology, medium-low technology, and low technology. In service industries we have five groups: knowledge-intensive services (KIS), high-tech KIS, market KIS (excluding financial intermediation and high-tech services), less-knowledge-intensive services (LKIS), and market LKIS. The firms that achieve the best results in terms of highest sales are medium-high- and low-technology firms in the manufacturing sector and LKIS and market LKIS firms in the service sector.

Based on the derived efficiency we examine the impact of the ownership structure on estimated efficiency. Ownership type and concentration has been recognized as an important determinant of firm performance in developed economies (Temouri et al., 2008; Hill and Snell, 1989) as well as emerging economies (Estrin et al., 2009; Pivovarsky, 2003). We define the ownership variables with respect to country-specific legal rules as argued in Gugler (2003). As shown in Hanousek et al. (2007a), holders of different concentration thresholds have under Czech law different opportunities to influence corporate governance. In particular, majority ownership (more than $50 \%$ of shares) grants the owner the right to staff management and supervisory boards, alter and transfer firms' assets and make crucial strategic decisions at general shareholder meetings. Through management and supervisory boards, majority ownership also facilitates more direct executive control of the company. On the other hand, minority owners with a block of at least $10 \%$ of shares are potentially important because the law entitles the holder of this stake to call general shareholder meetings and obstruct decisions by delaying implementation through lengthy court proceedings. These minority shareholders (including the state) may thus use their ownership position to delay or completely block the implementation of decisions by stronger shareholder(s).

Majority ownership represents a high degree of concentrated ownership, while minority ownership can be viewed as a form of moderately dispersed ownership. ${ }^{6}$ Based on the above distinction of ownership concentration, we define several specific ownership categories. Rather than using exact percentage stakes, we opt for dummy variables that differentiate various ownership categories and allow us to provide more comprehensive results. All ownership categories are exclusively defined and they are also distinguished for domestic and foreign owners, as well as those without a known domicile. The categories of foreign ownership defined below are based on stakes above $10 \%$ and are considered to represent FDI ownership.

\footnotetext{
${ }^{6}$ Highly dispersed ownership arises when the stake of the largest holder does not reach the legal (10 percent) minority.
} 
Majority ownership is a dummy variable that is coded 1 when an owner holds more than a 50\% stake in a firm and otherwise there is only dispersed ownership; it is coded 0 otherwise. This category provides the majority owner with effective control over the company.

Monitored majority ownership is a dummy variable that is coded 1 when there is majority ownership in a firm but at the same time there exists at least one minority owner with a stake higher than $10 \%$; it is coded 0 otherwise. This ownership category reflects the situation in firms where the majority owner is confronted with at least one non-marginal owner pursuing its own interest.

There are two minority-category variables. First, controlling minority ownership is a dummy variable that is coded 1 when an owner holds a stake in a firm that is greater than $10 \%$ and this stake is greater than the sum of all the remaining stakes that can be identified, e.g. the remaining stakes of all the listed companies. It is coded 0 otherwise. This is an extreme case of control provided through a minority stake in a company with highly dispersed ownership. It is a realistic category, as in numerous companies dispersed ownership prevents the emergence of larger stakes. This category has two implications relevant for our analysis. One, at general shareholder meetings dispersed owners would have to act in concert to override the decision of the single controlling minority owner. Two, according to the law, shareholders have to disclose their identities in order to commonly execute shareholder rights by agreement. In this case, their identities would be revealed and listed in the commercial registry, and the database would contain the ownership identities of highly dispersed owners.

Combined controlling minority ownership is the second minority category that is coded 1 when there are two owners whose combined stake exceeds $50 \%$ and 0 otherwise. These two owners cannot individually control the firm or act against each other as individually they do not have enough voting power. However, they may or may not coordinate their steps or form a coalition and control the company via the combined voting rights that give them a majority. As noted earlier, we are able to distinguish domestic and foreign owners for many of the firms in our data set. However, for all the categories defined above we introduce additional dummy variables to capture the ownership when the owner's domicile cannot be identified. Either an owner is listed in the database without a country code identifying its domicile, or a firm has a legal structure that prevents distinguishing between domestic and foreign owners; e.g., a firm with unregistered stocks. Finally, a constant 
captures the unknown ownership of a firm. In this case the firm either exhibits highly dispersed ownership or does not report on its ownership. ${ }^{7}$

\section{Empirical Results}

Initially we analyze how the distance from the efficiency frontier is affected by variables that are critical to a firm's production (capital and labor). We employ a likelihood ratio test to formally test for the efficiency frontier model. Based on the results we estimate the timevarying efficiency frontier specification and present the results in Table 2. The contribution of capital and labor to firm production differs as the coefficient associated with labor is uniformly larger than that of capital. This finding indicates that firms are on average more labor-intensive. Further, we also formally tested whether the sum of the coefficients associated with both inputs is statistically different from unity; this would indicate constantreturns-to-scale production. The results of these tests show that the sum of the coefficients is smaller than one (about 0.8 on average), a level indicating decreasing returns-to-scale. Hence, we can conclude that larger firms exhibit lower efficiency.

\subsection{Ownership effects}

In Table 3 we present the results of the determination of efficiency by ownership category without distinguishing among the technology-intensive or knowledge-intensive sectors in which firms operate. We present the ownership concentration categories in the left column. Each subsequent column then contains coefficients for the distance from the efficiency frontier for a specific ownership category and specific year. These coefficients should be interpreted in the following manner. A fully efficient firm would have a distance from the efficiency frontier equal to zero. Hence, the positive value of a statistically significant coefficient associated with an ownership category indicates that this ownership category moves a firm away from the efficiency frontier. In other words, a positive coefficient associated with a particular type of ownership category indicates that the specific ownership category is associated with a lower contribution to firm efficiency; larger a coefficient is, greater inefficiency it represents. On the other hand, a negative and statistically significant coefficient associated with a specific category indicates that the category helps to move a firm closer to the efficiency frontier - firm becomes more efficient, smaller a coefficient becomes. In order to improve the accessibility of our results we also present our findings in a graphical

\footnotetext{
${ }^{7}$ In our analysis we do not consider a category of highly dispersed ownership when owners hold stakes smaller than $10 \%$ in the firm. First, less-than-10\% ownership is not required to be reported by law. Hence, we are not able to completely trace all these stakes. Second, even when we are able to trace less-than-10\% stakes, their proportion in our sample is negligible (about 3\%).
} 
form in Figure 1, where we plot coefficient values along with 95\% confidence intervals. This way we are able to better trace the development of efficiency with respect to ownership type over time.

Majority ownership exhibits on average a strong impact on firm efficiency. This result is in accord with agency theory. Further, we can see that the coefficient values associated with foreign owners are consistently negative (coefficient range -0.020 to -0.069 ), a feature that indicates improving efficiency in foreign-majority-owned firms. In the case of domesticmajority-controlled firms, coefficients are positive and their values decrease over time (coefficient range 0.104 to 0.019 ). This finding indicates that domestic majority owners are less conducive to firms' efficiency but their impact improves over time. Hence, foreign owners contribute to a firm's efficiency considerably more than domestic owners. From Figure 1 we can see that while the impact of foreign owners is relatively steady, that of domestic owners is more pronounced. A comparison of the two trajectories hints at the potential convergence of the effect of the two majority ownerships in the future. In those firms where the domicile of the majority owner is unknown, the impact on efficiency is somewhere between foreign and domestic owners. A mix of foreign and domestic owners in firms with unknown majority owner's domicile might be a reason for this result. However, as we stated in the data section, we are unable to decipher this category any further.

In firms where a majority owner is confronted with the presence of a minority owner (or owners) the ownership structure is conducive to the firm's efficiency in general. This monitored majority helps to improve firm efficiency especially when the majority owner is of foreign origin as coefficient values that are positive in the beginning of the researched period turn negative from 2003. In terms of the domestic owners the lack of statistically significant coefficients precludes any firm conclusions, albeit the majority of the coefficients are negative. ${ }^{8}$ Further, the monitored foreign majority category does not correlate with firm efficiency at a better level than a simple foreign majority. This finding is important: it indicates that a positive disciplining effect on firm efficiency when a majority owner must account for the presence of an influential minority shareholder does not materialize.

Minority owners whose stakes are still larger than the combined stakes of the rest of the known owners also contribute to firm efficiency but the effect of controlling minority ownership is less conclusive for foreign owners due to statistically insignificant coefficients. Further, domestic minority owners impact firm efficiency to a slightly greater degree

\footnotetext{
${ }^{8}$ Lack of statistical significance can also mean that the category of monitored majority foreign ownership during the period 1998-2000 contains the most efficient firms as the coefficients are close to zero. The reason is that when we assess our hypotheses in effect we test that the coefficient equals zero. In the case of a very small and statistically insignificant coefficient, we are unable to reject the hypothesis that the distance from the efficiency frontier equals zero.
} 
(coefficient range -0.018 to -0.071 ) than foreign majority owners (coefficient range -0.020 to 0.069). This interesting result implies that domestic minority owners are effective not only in controlling firms but in improving their corporate governance. In any event, these results also show that ownership concentration enabling even weakly grounded control tends to bring positive results and significantly affect firm efficiency.

Minority owners whose combined shares provide them with a majority of the voting rights - combined controlling minority ownership - are a special ownership category in terms of contribution to firm efficiency. In this category two minority owners face a situation where neither of them can fully control the company and only coordinated steps in a functional coalition would enable them to jointly control the company. The inability to fully control a firm by one of the two minority owners resembles a "Mexican standoff". This slang term defines a stalemate or a confrontation that neither of the parties can win. To come out of the deadlock the parties must resolve the situation by negotiation, surrender, or attack. How does this arrangement work for firm efficiency? Foreign owners record positive and statistically significant coefficients for about the first half of the researched period while domestic owners record negative significant coefficients for the second half. Hence, foreign owners seem to struggle and are unable to cooperate to improve firm efficiency. The consistently negative coefficients in the case of domestic owners indicate that this ownership category is conducive to firm efficiency while foreign owners are not. Moreover, the negative coefficients associated with domestic owners hint at a peaceful use of power between the two minority shareholders and a contributing effect of this ownership arrangement with respect to firm efficiency. Alternatively, firms can be established from the beginning as having cooperating co-owners, so a deadlock is averted.

\subsection{Effects of firm characteristics}

In terms of firm characteristics the results show that the larger the firm is (measured by total assets) the further it is from the efficiency frontier, as witnessed by positive coefficients associated with the size variable. Hence, our findings show that larger firms are less efficient.

Similarly, more indebted firms are further from the efficiency frontier and hence, they are less efficient. Our result is supported by the recent analysis of Marin and Schnitzer (2011), who show that of all the external and mixed funding of German and Austrian FDI to Eastern Europe, including the Czech Republic, thirty to forty percent comes from local sources either through a loan by a local bank in the host country or by equity raised in the host country. Thus, in roughly $15 \%$ of the cases an FDI investment in Eastern Europe does not involve a net capital flow that leaves enough room for the large indebtedness of firms. 
In terms of age we find that older firms are more efficient. As a robustness check we also performed additional estimations to account for the possibility of problems with incomplete reporting and misreporting, which is often encountered in small firms. For a robustness check we accounted for firms with less than 25 or 10 employees. The obtained results (not reported but available upon request) are not materially different and correspond to the pattern of the reported coefficients for the whole sample presented above.

\subsection{Effects of economic sectors}

As a next step we estimate how the firm efficiency is affected when we distinguish between the different economic sectors in which firms operate (manufacturing and services) and the different technology intensity the firms exhibit. Our additional analysis serves also as a robustness check. In Tables 4 and 5 we present results that distinguish ownership effects depending on the economic sectors firms operate in. We distinguish four manufacturing sectors based on technology levels (Table 4) and five service sectors based on the knowledge intensity they represent (Table 5). As mentioned in Section 3, this division strictly adheres to the methodology of Eurostat.

From Table 4 we can see that on average the owners of firms belonging to the two extremes (high- and low-technology sectors) are the most conducive to firm efficiency. ${ }^{9}$ Then, in these sectors, foreign majority and domestic minority owners tend to be associated with the highest efficiency in the firms they control. It is also interesting to note that minority domestic owners who are able to exert control over firms because the rest of the ownership is dysfunctionally dispersed exhibit a comparably high degree of efficiency in firms across all four sectors. Finally, coalitions of two domestic minority owners with the ability to jointly control firms drive efficiency in high-, medium-low-, and low-technology sectors and by this token they accord with the general pattern.

The results for firms operating in services are presented in Table 5. On average the owners of firms belonging to the sectors of knowledge-intensive services (KIS), high-tech KIS and market KIS are most conducive to firm efficiency (see footnote 9). They do quite well with foreign majority and monitored majority owners, driving the best efficiency results. On the contrary, firms in the sectors of less-knowledge-intensive services (LKIS) and market LKIS exhibit worse results, which are witnessed by relevant coefficients.

\footnotetext{
${ }^{9}$ Part of this result can be explained by the fact that the innovation process in new EU economies is dominated by foreign multinationals (Uzagalieva et al., 2012). Further, Hanousek et al. (2011) show that local firms in the new EU markets experience efficiency gains if they supply industries with a higher share of foreign firms or if foreign firms sell to them.
} 
Yet another pattern emerges when we compare specific ownership categories across two distinctive economic groups. Differences in contributions to firm efficiency between foreign and domestic majority owners are smaller for firms operating in services than in manufacturing sectors. A similar pattern can be detected for firms controlled by combined controlling minority owners. On the other hand differences in contribution to efficiency between foreign and domestic owners are smaller in firms controlled by monitored majority and controlling minority owners operating in manufacturing sectors. Hence, when we put the above results into perspective with those reported in Table 3, controlling minority domestic owners operating firms in manufacturing sectors represent the group of owners that is most conducive to improving efficiency in Czech firms. In terms of firm characteristics (size, debt, and age) their effects are quite balanced across the firms in the manufacturing and service sectors and they are also similar to the results reported in Table 3.

\section{Conclusion}

We analyze the evolution of efficiency in Czech firms during the period 1998-2007 and how efficiency is affected by firm ownership structure. We provide evidence that ownership structure matters quite a lot and indicate numerous detailed results.

Our key result is that highly concentrated ownership is consistently beneficial to firm efficiency. This finding is in favor of agency theory and in line with the general key results summarized by Estrin et al. (2009). Concentrated foreign ownership exhibits superior results when compared to domestic ownership, a finding that indicates the beneficial effects of FDI at the microeconomic level. Further, we show that a simple majority is not necessarily the best structure to improve efficiency. Minority domestic owners are conducive to firm efficiency at a slightly higher level than a pure majority. Further, we find that cooperative coalitions of domestic minority owners that allow for control in a firm bring good results. Minority owners who share control in a firm may end up rivaling each other, which is not conducive to efficiency. However, our evidence points out that domestic minority owners do cooperate and improve the efficiency of their firms while we do not see this evidence for the foreign-owned firms.

In order to analyze differences among manufacturing and services firms we perform an additional analysis that also serves as a robustness check. We estimate how sensitive the efficiency effects are with respect to the different economic sectors in which firms operate (manufacturing and services) and to the different technology intensity the firms exhibit. We show that that firms belonging to opposite technology poles (high- and low-technology sectors) exhibit equal and very good results. In terms of sectors, differences in the impact on 
firm efficiency are smaller in the case of majority and combined controlling minority owners for firms in manufacturing sectors. Differences in impact on firm efficiency between foreign and domestic owners are less pronounced for monitored majority and controlling majority owners operating in services. As services are more aimed at the local market the domesticcontrolled firms may benefit from better knowledge of the local market. This knowledge and less emphasis on export might contribute to eliminate differences among domestic and foreign owners in firms operating in services.

Overall, we find evidence of improving efficiency among the firms in our sample. This is certainly a positive feature hinting at improved management and corporate governance in Czech firms. 


\section{References}

Aigner, D., Lovell, C., \& Schmidt, P. (1977). Formulation and estimation of stochastic frontier production functions. Journal of Econometrics, 6, 21-37.

Aussenegg, W., Jelic, R., 2007.The Operating Performance of Newly Privatised Firms in Central European Transition Economies. European Financial Management, 13(5), 853-879.

Barro, R. J. (1991). Economic Growth in Cross-Section of Countries. Quarterly Journal of Economics, 106(2), 407-443.

Battese, G., Coelli, T. (1995). A model for technical inefficiency effect in a stochastic frontier production function. Empirical Economics, 20, 325-332.

Bjørnskov, C., Philipp Meinen, JørgenUlff-Møller Nielsen and Philipp J.H. Schröder, 2009. Lobbying for anti-dumping measures: Does distance from Brussels matter? Working paper, Department of Economics, Aarhus University

Boycko, M., Shleifer, A. and Vishny, R. W. (1996). A theory of privatization. Economic Journal 106(435), 309-319.

Blomström, M., Globerman, S., and A. Kokko (2001).The Determinants of Host Country Spillovers from Foreign Direct Investment. In N. Pain (ed.), Inward Investment, Technological Change and Growth. Basingstoke: Palgrave.

Brada, J., King, A. (1994). Differences in the technical and allocative efficiency of private and socialized agricultural units in pre-transformation Poland. Economic Systems, 18(4), 363-376.

Brada, J., King, A. and Ma, C. (1994). Industrial economics of the transition: determinants of enterprise efficiency in Czechoslovakia and Hungary. Oxford Economic Papers, 49, 104-127.

Brown, J. D., Earle, J. S and Telegdy, Á. (2006). The productivity Effects of Privatization: Longitudinal Estimates from Hungary, Romania, Russia, and Ukraine. Journal of Political Economy 114(1), 61-99.

Claessens, Stijn, and Simeon Djankov. 1999. "Ownership Concentration and Corporate Performance in the Czech Republic." Journal of Comparative Economics 27(3): 498513.

Coelli T., Prasada Rao D.S. and G. E. Battese, 2005. An Introduction to Efficiency and Productivity Analysis, Kluwer Academic Publishers.

Coelli, T.J. (2005).Recent Developments in Frontier Modelling and Efficiency Measurement. Australian Journal of Agricultural Economics 39(3), 219-45.

Cornwell, C., Schmidt, P. and Sickles, R. C. (1990) Production Frontiers with Cross-Sectional and Time-Series Variation in Efficiency Levels, Journal of Econometrics 46:185-200.

Crinò, R. (2005). Wages, Skills and Integration in Poland, Hungary and the Czech Republic: an Industry-Level Analysis, Transition Studies Review, 12, 432-45.

Demsetz, H. (1983). The Structure of Ownership and the Theory of the Firm. Journal of Law and Economics, 16, 375-390.

Demsetz, H., and Lehn, K. (1985). The Structure of Corporate Ownership: Causes and Consequences. Journal of Political Economy, 93, 1153-1177.

Djankov, S., and Hoekman, B.M, 2000. Foreign Investment and Productivity Growth in Czech Enterprises. World Bank Economic Review, 14(1), 49-64. 
Estrin, S., Hanousek, J., Kočenda, E., Svejnar, J., 2009. Effects of Privatization and Ownership in Transition Economies. Journal of Economic Literature, 47(3), 699-728.

Gorodnichenko, Y. and Schnitzer, M. (2010), Financial constraints and innovation: Why poor countries don't catch up. Working Paper 15792. National Bureau of Economic Research, Cambridge, MA

Gugler, K., 2003. Corporate Governance, Dividend Payout Policy, and the Interrelation between Dividends, R\&D, and Capital Investment. Journal of Banking and Finance 27, 1297-1321.

Hájková, D. and Hurník, J. (2007). Cobb-Douglas Production Function: The Case of a Converging Economy. Czech Journal of Economics and Finance, 57 (9-10), 465-476.

Hanousek, J., Kočenda, E., Maurel, M., 2011. Direct and indirect effects of FDI in emerging European markets: Survey and Meta-analysis. Economic Systems, 35(3), 301-322.

Hanousek, J., Kočenda, E. and Svejnar, J. (2007a). Origin and concentration: Corporate ownership, control and performance in firms after privatization. Economics of Transition 15(1), 1-31.

Hanousek, J., Kočenda E. and Svejnar, J. (2009). Divestitures, Privatization and Corporate Performance in Emerging Markets. Economics of Transition 17(1), 43-73.

Hanousek, J., Kočenda, E., Ondko, P., (2007b). The Banking Sector in New EU Member Countries: A Sectoral Financial Flows Analysis. Czech Journal of Economics and Finance, 57(5-6), 200-224.

Hill, W. L. and Snell, S. A. (1989). Effects of Ownership Structure and Control on Corporate Productivity. The Academy of Management Journal, 32(1), 25-46.

Ickes, B., and Ryterman, R. (1993). Entry without exit: economic selection under socialism. Pennsylvania State - Department of Economics Papers No. 10-93-4a.

IMF, 2009. Balance of Payments and International Investment Position Manual: Sixth Edition. Washington, DC: International Monetary Fund.

Jandik, T. and Rennie, C.G., 2008. The Evolution of Corporate Governance and Firm Performance in Transition Economies: The Case of Sellier and Bellot in the Czech Republic. European Financial Management, 14(4), 747-791.

Javorcik, B.S., 2004. Does Foreign Direct Investment Increase the Productivity of Domestic Firms? In Search of Spillovers through Backward Linkages. American Economic Review, 94(3), 605-627.

Khumbhakar, S.C., 1990. Production Frontiers, Panel Data, and Time-Varying Technical Inefficiency. Journal of Econometrics 46: 201-211.

Kim, C., Mauer, D. C. and Sherman A. E. (1998). The determinants of corporate liquidity: theory and evidence. Journal of Financial and Quantitative Analysis, 33(3), 335-359.

Kočenda, E., 2001. Macroeconomic Convergence in Transition Countries. Journal of Comparative Economics, 29(1), 1-23.

Konings, J., Repkin, A. (1998). How efficient are firms in transition countries? Firm-level evidence from Bulgaria and Romania. Transition Economics, No.1839, 1-26.

Kosová, R. (2009). Do Foreign Firms Crowd Out Domestic Firms? Evidence from the Czech Republic. The Review of Economics and Statistics, 92 (4), 861-881.

Krueger, A. B. and L. H. Summers (1988). Efficiency Wages and the Inter-Industry Wage Structure, Econometrica, 56(2), 259-293. 
Laafia, I. (2002). Employment in High Tech and Knowledge Intensive Sectors in the EU Continues to Grow in 2001. Eurostat, Statistics in Focus: Science and Technology 9(4), 1-8.

La Porta, Rafael, Florencio Lopez-de-Silanes, and Andrei Shleifer, 1999, Corporate ownership around the world, Journal of Finance 54, 471-517.

Linz, S., Rahkovsky, I. (2009). Analyzing the technical efficiency of Russian firms: 19921995. (April 27, 2009). Available at SSRN: http://ssrn.com/abstract=1395803

Marin, D., Schnitzer, M., 2011. When is FDI a capital flow? European Economic Review 55, 845-861.

Mathur, I., Singh, M., Gleason, K.C., 2004. Multinational Diversification and Corporate Performance: Evidence from European Firms. European Financial Management, 10(3), 439-464.

Meeusen, W., van den Broeck, J. (1977). Efficiency estimation from Cobb-Douglas production functions with composed error. International Economic Review, 18(2), 435-444.

Melitz, M. J., (2003). The Impact of Trade on Intra-Industry Reallocations and Aggregate Industry Productivity. Econometrica 71 (6), 1695-1725.

OECD, 2008. OECD Benchmark definition of foreign direct investment: fourth edition. Paris: Organisation for Economic Co-operation and Development.

Pavitt, K., (1984). Sectoral patterns of technical change: towards a theory and a taxonomy. Research Policy 13, 343-373.

Pivovarsky, A. (2003). Ownership Concentration and Performance in Ukraine's Privatized Enterprises.IMF Staff Papers 50(1), 10-42.

Ross, S. A., Westerfield, R. W. and Jeffrey, J. (2005), Corporate Finance, $7^{\text {th }}$ International edition; McGraw Hill.

Sabirianova Peter, K., Svejnar, J. and Terrell, K. (2005a). Foreign Investment, Corporate Ownership, and Development: Are Firms in Emerging Markets Catching up to the World Standard? IZA DP1457.

Sabirianova Peter, K., Svejnar, J. and Terrell, K. (2005b). Distance to the efficiency frontier and foreign direct investment spillovers. Journal of the European Economic Association, 3(2-3), 576-586.

Shleifer, Andrei, and Robert W. Vishny. 1997. A Survey of Corporate Governance. Journal of Finance, 52(2): 737-83.

Temouri, Y., N.L. Driffield and D.A. Higón, 2008. Analysis of productivity differences among foreign and domestic firms: Evidence from Germany, The Review of World Economics, 144(1), 32-54.

Thomsen, S., and Pedersen, T. (1998).Industry and ownership structure. International Review of Law and Economics, 18, 386-404.

Uzagalieva, A., Kočenda, E., and Menezes, A., 2012. Technological Innovation in New European Union Markets. Forthcoming in Emerging Markets Finance and Trade.

Weill, L., 2008. Leverage and Corporate Performance: Does Institutional Environment Matter? Small Business Economics 30:251-265 
Table 1: Simple descriptive statistics

\begin{tabular}{c|cccc}
\hline Year & Sales & Working capital & $\begin{array}{c}\text { Number of } \\
\text { employees }\end{array}$ & $\begin{array}{c}\text { Number of } \\
\text { firms }\end{array}$ \\
\hline \hline 1998 & 13505503 & 59467 & 242.2 & 4240 \\
1999 & 10446056 & 47631 & 213.0 & 5036 \\
2000 & 10549254 & 51124 & 195.5 & 6015 \\
2001 & 10709491 & 49929 & 174.1 & 6926 \\
2002 & 7044422 & 29000 & 96.3 & 13350 \\
2003 & 6506458 & 22325 & 75.1 & 19700 \\
2004 & 6080603 & 18470 & 61.0 & 29523 \\
2005 & 5616113 & 16950 & 52.1 & 33470 \\
2006 & 5590190 & 16331 & 42.3 & 38255 \\
2007 & 7821798 & 20173 & 44.8 & 34642 \\
\hline \hline
\end{tabular}

Table 2: First step - Efficiency frontier

\begin{tabular}{lrrr}
\hline NACE Grouping & $\begin{array}{r}\text { Constant } \\
\text { term }\end{array}$ & $\begin{array}{r}\text { Log Working } \\
\text { Capital }\end{array}$ & $\begin{array}{r}\text { Log Number } \\
\text { of Employees }\end{array}$ \\
\hline \hline Manufacturing industries & & & \\
High technology & 11.424 & 0.294 & 0.550 \\
Medium-high technology & 11.697 & 0.297 & 0.491 \\
Medium-low technology & 11.856 & 0.277 & 0.494 \\
Low technology & 11.818 & 0.274 & 0.493 \\
\hline Service industries & & & \\
Knowledge-intensive services (KIS) & 12.107 & 0.215 & 0.563 \\
High-tech KIS & 12.035 & 0.222 & 0.571 \\
Market KIS * & 12.091 & 0.221 & 0.559 \\
Less-knowledge-intensive services (LKIS) & 11.978 & 0.292 & 0.510 \\
Market services less KIS & 11.971 & 0.294 & 0.510 \\
\hline \hline
\end{tabular}

Notes:

We use the industry classification according to OECD-Eurostat (Laafia, 2002). It is also available at http://epp.eurostat.ec.europa.eu/cache/ITY_SDDS/Annexes/htec_esms_an2.pdf . In the table we present the weighted averages of the estimated coefficients; weights correspond to the number of observations.

* Market KIS excludes financial intermediation and high-tech services. 
Table 3: Effects of ownership structure on efficiency

\begin{tabular}{|c|c|c|c|c|c|c|c|c|c|c|}
\hline Ownership category & 1998 & 1999 & 2000 & 2001 & 2002 & 2003 & 2004 & 2005 & 2006 & 2007 \\
\hline Majority foreign & $\begin{array}{l}-0.020^{* * *} \\
(0.010)\end{array}$ & $\begin{array}{c}-0.030^{* * * *} \\
(0.009)\end{array}$ & $\begin{array}{c}-0.030^{* * * *} \\
(0.008)\end{array}$ & $\begin{array}{l}-0.035^{* * *} \\
(0.008)\end{array}$ & $\begin{array}{c}-0.048^{* * * *} \\
(0.006)\end{array}$ & $\begin{array}{c}-0.060^{* * * *} \\
(0.006)\end{array}$ & $\begin{array}{c}-0.060^{* * * *} \\
(0.006)\end{array}$ & $\begin{array}{c}-0.059^{* * *} \\
(0.005)\end{array}$ & $\begin{array}{l}-0.064^{* * * *} \\
(0.005)\end{array}$ & $\begin{array}{c}-0.069^{* * * *} \\
(0.006)\end{array}$ \\
\hline Majority domestic & $\begin{array}{c}0.104^{* * *} \\
(0.014)\end{array}$ & $\begin{array}{l}0.072^{\text {**** }} \\
(0.012)\end{array}$ & $\begin{array}{l}0.069^{* * *} \\
(0.010)\end{array}$ & $\begin{array}{c}0.054^{* * * *} \\
(0.009)\end{array}$ & $\begin{array}{l}0.025^{* * * *} \\
(0.007)\end{array}$ & $\begin{array}{l}0.022^{* * *} \\
(0.006)\end{array}$ & $\begin{array}{l}0.025^{* * * *} \\
(0.007)\end{array}$ & $\begin{array}{c}0.025^{* * *} \\
(0.006)\end{array}$ & $\begin{array}{c}0.019^{* * * *} \\
(0.006)\end{array}$ & $\begin{array}{c}0.003 \\
(0.006)\end{array}$ \\
\hline Majority unknown & $\begin{array}{c}0.112 \\
(0.079) \\
\end{array}$ & $\begin{array}{c}-0.099^{* *} \\
(0.050)\end{array}$ & $\begin{array}{c}0.013 \\
(0.036) \\
\end{array}$ & $\begin{array}{l}-0.013 \\
(0.057)\end{array}$ & $\begin{array}{c}-0.060^{* *} \\
(0.029)\end{array}$ & $\begin{array}{l}-0.006 \\
(0.006) \\
\end{array}$ & $\begin{array}{c}-0.010^{* *} \\
(0.004)\end{array}$ & $\begin{array}{c}-0.019^{* * *} \\
(0.006)\end{array}$ & $\begin{array}{c}-0.019^{* * * *} \\
(0.006) \\
\end{array}$ & $\begin{array}{c}-0.021^{* * * *} \\
(0.007)\end{array}$ \\
\hline $\begin{array}{l}\text { Monitored majority } \\
\text { foreign }\end{array}$ & $\begin{array}{l}0.038^{* *} \\
(0.016)\end{array}$ & $\begin{array}{l}0.024^{* * * *} \\
(0.014)\end{array}$ & $\begin{array}{l}0.040^{* * * * *} \\
(0.013)\end{array}$ & $\begin{array}{l}0.029^{* * *} \\
(0.013)\end{array}$ & $\begin{array}{c}0.010 \\
(0.011)\end{array}$ & $\begin{array}{l}-0.017^{*} \\
(0.010)\end{array}$ & $\begin{array}{c}-0.030^{* * * *} \\
(0.009)\end{array}$ & $\begin{array}{l}-0.016^{*} \\
(0.009)\end{array}$ & $\begin{array}{l}-0.016^{*} \\
(0.009)\end{array}$ & $\begin{array}{l}-0.021^{*} \\
(0.010)\end{array}$ \\
\hline $\begin{array}{l}\text { Monitored majority } \\
\text { domestic }\end{array}$ & $\begin{array}{l}-0.020 \\
(0.087)\end{array}$ & $\begin{array}{l}-0.048 \\
(0.063)\end{array}$ & $\begin{array}{c}0.058 \\
(0.043)\end{array}$ & $\begin{array}{c}0.038 \\
(0.034)\end{array}$ & $\begin{array}{c}-0.047^{* *} \\
(0.023)\end{array}$ & $\begin{array}{l}-0.014 \\
(0.025)\end{array}$ & $\begin{array}{l}-0.034 \\
(0.035)\end{array}$ & $\begin{array}{l}-0.011 \\
(0.026)\end{array}$ & $\begin{array}{l}-0.023 \\
(0.028)\end{array}$ & $\begin{array}{l}-0.026 \\
(0.031)\end{array}$ \\
\hline $\begin{array}{l}\text { Monitored majority } \\
\text { unknown }\end{array}$ & $\begin{array}{c}0.068 \\
(0.137) \\
\end{array}$ & $\begin{array}{c}0.151 \\
(0.114) \\
\end{array}$ & $\begin{array}{c}0.023 \\
(0.057)\end{array}$ & $\begin{array}{l}-0.055 \\
(0.113)\end{array}$ & $\begin{array}{c}0.059 \\
(0.066) \\
\end{array}$ & $\begin{array}{c}0.008 \\
(0.011) \\
\end{array}$ & $\begin{array}{l}0.014^{*} \\
(0.008)\end{array}$ & $\begin{array}{l}-0.001 \\
(0.011)\end{array}$ & $\begin{array}{c}0.009 \\
(0.011) \\
\end{array}$ & $\begin{array}{l}-0.005 \\
(0.012) \\
\end{array}$ \\
\hline $\begin{array}{l}\text { Controlling minority } \\
\text { foreign }\end{array}$ & $\begin{array}{l}0.059^{*} \\
(0.034)\end{array}$ & $\begin{array}{l}0.041^{*} \\
(0.021)\end{array}$ & $\begin{array}{l}0.056^{* *} \\
(0.024)\end{array}$ & $\begin{array}{c}0.019 \\
(0.019)\end{array}$ & $\begin{array}{l}-0.008 \\
(0.012)\end{array}$ & $\begin{array}{l}-0.015 \\
(0.013)\end{array}$ & $\begin{array}{l}-0.001 \\
(0.014)\end{array}$ & $\begin{array}{l}-0.001 \\
(0.013)\end{array}$ & $\begin{array}{l}-0.009 \\
(0.014)\end{array}$ & $\begin{array}{l}-0.020^{*} \\
(0.011)\end{array}$ \\
\hline $\begin{array}{l}\text { Controlling minority } \\
\text { domestic }\end{array}$ & $\begin{array}{l}-0.018^{*} \\
(0.010)\end{array}$ & $\begin{array}{c}-0.024^{* *} \\
(0.010)\end{array}$ & $\begin{array}{c}-0.039^{* * * *} \\
(0.009)\end{array}$ & $\begin{array}{c}-0.045^{* * *} \\
(0.010)\end{array}$ & $\begin{array}{c}-0.063^{* * *} \\
(0.009)\end{array}$ & $\begin{array}{c}-0.072^{* * *} \\
(0.009)\end{array}$ & $\begin{array}{c}-0.071^{* * *} \\
(0.009)\end{array}$ & $\begin{array}{c}-0.061^{* * *} \\
(0.009)\end{array}$ & $\begin{array}{c}-0.059^{* * * *} \\
(0.009) \\
\end{array}$ & $\begin{array}{c}-0.067^{\text {**** }} \\
(0.009)\end{array}$ \\
\hline $\begin{array}{l}\text { Combined controlling } \\
\text { minority foreign }\end{array}$ & $\begin{array}{c}0.055 \\
(0.061)\end{array}$ & $\begin{array}{l}0.151^{* *} \\
(0.070)\end{array}$ & $\begin{array}{l}0.077^{*} \\
(0.046)\end{array}$ & $\begin{array}{l}0.148^{\text {***** }} \\
(0.039)\end{array}$ & $\begin{array}{l}0.050^{* *} \\
(0.025)\end{array}$ & $\begin{array}{l}0.031^{* * *} \\
(0.014)\end{array}$ & $\begin{array}{c}0.023 \\
(0.028)\end{array}$ & $\begin{array}{c}0.021 \\
(0.028)\end{array}$ & $\begin{array}{c}0.019 \\
(0.028)\end{array}$ & $\begin{array}{c}0.012 \\
(0.031)\end{array}$ \\
\hline $\begin{array}{l}\text { Combined controlling } \\
\text { minority domestic }\end{array}$ & $\begin{array}{l}-0.002 \\
(0.011) \\
\end{array}$ & $\begin{array}{l}-0.002 \\
(0.010) \\
\end{array}$ & $\begin{array}{c}0.007 \\
(0.010) \\
\end{array}$ & $\begin{array}{l}-0.003 \\
(0.010)\end{array}$ & $\begin{array}{c}0.004 \\
(0.008) \\
\end{array}$ & $\begin{array}{l}-0.013^{*} \\
(0.007)\end{array}$ & $\begin{array}{c}-0.021^{* * *} \\
(0.007)\end{array}$ & $\begin{array}{c}-0.019^{* * * *} \\
(0.007) \\
\end{array}$ & $\begin{array}{c}-0.023^{* * * *} \\
(0.007) \\
\end{array}$ & $\begin{array}{c}-0.034^{* * *} \\
(0.007)\end{array}$ \\
\hline $\log$ (Total assets) & $\begin{array}{c}0.039^{* * *} \\
(0.002)\end{array}$ & $\begin{array}{l}0.040^{* * *} \\
(0.002)\end{array}$ & $\begin{array}{l}0.043^{\text {**** }} \\
(0.002)\end{array}$ & $\begin{array}{l}0.046^{\text {**** }} \\
(0.001)\end{array}$ & $\begin{array}{l}0.051^{* * *} \\
(0.001)\end{array}$ & $\begin{array}{l}0.054^{* * *} \\
(0.001)\end{array}$ & $\begin{array}{l}0.057^{* * *} \\
(0.001)\end{array}$ & $\begin{array}{l}0.059^{* * * *} \\
(0.001)\end{array}$ & $\begin{array}{c}0.059^{* * *} \\
(0.001)\end{array}$ & $\begin{array}{l}0.061^{* * * *} \\
(0.001)\end{array}$ \\
\hline Debt ratio (percent) & $\begin{array}{c}0.073^{* * * *} \\
(0.003)\end{array}$ & $\begin{array}{c}0.041^{\text {**** }} \\
(0.002)\end{array}$ & $\begin{array}{c}0.017^{* * * *} \\
(0.001)\end{array}$ & $\begin{array}{c}0.000 \\
(0.000)\end{array}$ & $\begin{array}{c}0.010^{* * * *} \\
(0.001)\end{array}$ & $\begin{array}{c}0.005^{* * * *} \\
(0.001)\end{array}$ & $\begin{array}{c}0.004^{\text {*** }} \\
(0.000)\end{array}$ & $\begin{array}{c}0.002^{* * * *} \\
(0.000)\end{array}$ & $\begin{array}{c}0.001^{* * *} \\
(0.000)\end{array}$ & $\begin{array}{c}0.005^{* * * *} \\
(0.001)\end{array}$ \\
\hline Age of the firm & $\begin{array}{c}-0.004^{* * *} \\
(0.001)\end{array}$ & $\begin{array}{l}-0.005^{* * *} \\
(0.001)\end{array}$ & $\begin{array}{c}-0.006^{* * *} \\
(0.001)\end{array}$ & $\begin{array}{c}-0.007^{* * *} \\
(0.001)\end{array}$ & $\begin{array}{c}-0.008^{* * *} \\
(0.000)\end{array}$ & $\begin{array}{c}-0.008^{* * *} \\
(0.000)\end{array}$ & $\begin{array}{c}-0.008^{* * *} \\
(0.000)\end{array}$ & $\begin{array}{c}-0.008^{* * *} \\
(0.000)\end{array}$ & $\begin{array}{c}-0.007^{* * *} \\
(0.000)\end{array}$ & $\begin{array}{c}-0.007^{* * * *} \\
(0.000)\end{array}$ \\
\hline Constant & $\begin{array}{c}-0.389^{* * *} \\
(0.033) \\
\end{array}$ & $\begin{array}{c}-0.338^{* * *} \\
(0.030)\end{array}$ & $\begin{array}{c}-0.328^{\text {**** }} \\
(0.025)\end{array}$ & $\begin{array}{l}-0.320^{* * * *} \\
(0.020) \\
\end{array}$ & $\begin{array}{c}-0.374^{* * * *} \\
(0.013)\end{array}$ & $\begin{array}{c}-0.381^{* * *} \\
(0.010)\end{array}$ & $\begin{array}{c}-0.404^{* * *} \\
(0.008) \\
\end{array}$ & $\begin{array}{c}-0.414^{* * *} \\
(0.007)\end{array}$ & $\begin{array}{c}-0.421^{* * * *} \\
(0.007)\end{array}$ & $\begin{array}{c}-0.439^{* * * *} \\
(0.008)\end{array}$ \\
\hline R-squared & 0.166 & 0.137 & 0.144 & 0.160 & 0.206 & 0.228 & 0.237 & 0.249 & 0.248 & 0.256 \\
\hline $\mathrm{N}$ & 4240 & 5036 & 6015 & 6926 & 13346 & 19696 & 29514 & 33458 & 38238 & 34635 \\
\hline
\end{tabular}

Note: ${ }^{* * * * *}$, and ${ }^{*}$ denote significance at the $1 \%, 5 \%$, and $10 \%$ levels, respectively. Standard errors are shown in parentheses and refer to the efficiency estimation stage. 
Table 4: Ownership effects in manufacturing industries - Sectors by EUROSTAT; all years

\begin{tabular}{|c|c|c|c|c|}
\hline \multirow[b]{2}{*}{ Ownership category } & \multicolumn{4}{|c|}{ Technology } \\
\hline & High & $\begin{array}{l}\text { Medium- } \\
\text { high }\end{array}$ & Medium-low & Low \\
\hline Majority foreign & $\begin{array}{c}-0.093^{* * *} \\
(0.006)\end{array}$ & $\begin{array}{c}-0.064^{* * *} \\
(0.007)\end{array}$ & $\begin{array}{c}-0.029^{\text {**** }} \\
(0.007)\end{array}$ & $\begin{array}{c}-0.088^{\text {*** }} \\
(0.005)\end{array}$ \\
\hline Majority domestic & $\begin{array}{c}0.049^{* * *} \\
(0.006)\end{array}$ & $\begin{array}{l}0.034^{* * *} \\
(0.008)\end{array}$ & $\begin{array}{l}0.025^{* * *} \\
(0.009)\end{array}$ & $\begin{array}{l}0.013^{* *} \\
(0.005)\end{array}$ \\
\hline Majority unknown & $\begin{array}{l}-0.013^{*} \\
(0.007)\end{array}$ & $\begin{array}{l}-0.018^{*} \\
(0.010)\end{array}$ & $\begin{array}{l}-0.009 \\
(0.011) \\
\end{array}$ & $\begin{array}{c}0.005 \\
(0.007) \\
\end{array}$ \\
\hline Monitored majority foreign & $\begin{array}{c}-0.049^{* * *} \\
(0.010)\end{array}$ & $\begin{array}{c}-0.027^{* *} \\
(0.012)\end{array}$ & $\begin{array}{l}-0.016 \\
(0.011)\end{array}$ & $\begin{array}{c}-0.073^{* * *} \\
(0.009)\end{array}$ \\
\hline Monitored majority domestic & $\begin{array}{c}-0.063^{* * *} \\
(0.023)\end{array}$ & $\begin{array}{l}0.053^{* *} \\
(0.026)\end{array}$ & $\begin{array}{c}0.032 \\
(0.037)\end{array}$ & $\begin{array}{l}-0.027 \\
(0.026)\end{array}$ \\
\hline Monitored majority unknown & $\begin{array}{l}-0.010 \\
(0.012) \\
\end{array}$ & $\begin{array}{l}-0.021 \\
(0.023)\end{array}$ & $\begin{array}{l}-0.019 \\
(0.029) \\
\end{array}$ & $\begin{array}{l}-0.001 \\
(0.015) \\
\end{array}$ \\
\hline Controlling minority foreign & $\begin{array}{l}-0.020 \\
(0.013)\end{array}$ & $\begin{array}{c}0.028 \\
(0.018)\end{array}$ & $\begin{array}{c}-0.043^{* *} \\
(0.018)\end{array}$ & $\begin{array}{c}0.038^{\text {**** }} \\
(0.013)\end{array}$ \\
\hline $\begin{array}{l}\text { Controlling minority } \\
\text { domestic }\end{array}$ & $\begin{array}{c}-0.107^{* * *} \\
(0.009)\end{array}$ & $\begin{array}{c}-0.041^{* * *} \\
(0.010)\end{array}$ & $\begin{array}{c}-0.104^{* * *} \\
(0.009)\end{array}$ & $\begin{array}{c}-0.106^{* * *} \\
(0.008)\end{array}$ \\
\hline $\begin{array}{l}\text { Combined controlling } \\
\text { minority foreign }\end{array}$ & $\begin{array}{c}0.036 \\
(0.023)\end{array}$ & $\begin{array}{l}-0.005 \\
(0.035)\end{array}$ & $\begin{array}{l}0.161^{* * *} \\
(0.037)\end{array}$ & $\begin{array}{l}0.131^{* * *} \\
(0.028)\end{array}$ \\
\hline $\begin{array}{l}\text { Combined controlling } \\
\text { minority domestic }\end{array}$ & $\begin{array}{c}-0.080^{* * *} \\
(0.007)\end{array}$ & $\begin{array}{l}0.023^{* *} \\
(0.010)\end{array}$ & $\begin{array}{c}-0.061^{* * * *} \\
(0.008)\end{array}$ & $\begin{array}{c}-0.063^{* * *} \\
(0.007)\end{array}$ \\
\hline $\log$ (Total assets) & $\begin{array}{c}0.055^{* * *} \\
(0.001)\end{array}$ & $\begin{array}{l}0.041^{* * *} \\
(0.001)\end{array}$ & $\begin{array}{l}0.049^{* * *} \\
(0.001)\end{array}$ & $\begin{array}{c}0.037^{* * *} \\
(0.001)\end{array}$ \\
\hline Debt ratio (percent) & $\begin{array}{l}0.006^{* * *} \\
(0.001)\end{array}$ & $\begin{array}{l}-0.002 \\
(0.002)\end{array}$ & $\begin{array}{l}0.001^{* * * *} \\
(0.000)\end{array}$ & $\begin{array}{c}0.003^{* * *} \\
(0.001)\end{array}$ \\
\hline Age of the firm & $\begin{array}{c}-0.006^{* * *} \\
(0.000) \\
\end{array}$ & $\begin{array}{c}-0.008^{* * *} \\
(0.000)\end{array}$ & $\begin{array}{c}-0.004^{* * *} \\
(0.000) \\
\end{array}$ & $\begin{array}{c}-0.004^{* * *} \\
(0.000)\end{array}$ \\
\hline Constant & $\begin{array}{c}-0.404^{* * * *} \\
(0.011)\end{array}$ & $\begin{array}{c}-0.214^{* * *} \\
(0.017) \\
\end{array}$ & $\begin{array}{c}-0.365^{\text {**** }} \\
(0.017) \\
\end{array}$ & $\begin{array}{c}-0.189^{* * * *} \\
(0.011)\end{array}$ \\
\hline R-squared & 0.259 & 0.208 & 0.205 & 0.168 \\
\hline $\mathrm{N}$ & 17352 & 7415 & 8122 & 14968 \\
\hline
\end{tabular}

Note: ${ }^{* * *},{ }^{* *}$, and ${ }^{*}$ denote significance at the $1 \%, 5 \%$, and $10 \%$ levels, respectively. 
Table 5: Ownership effects in service sectors - Sectors by EUROSTAT; all years

\begin{tabular}{|c|c|c|c|c|c|}
\hline Ownership category & $\begin{array}{r}\text { Knowledge- } \\
\text { intensive } \\
\text { services } \\
\text { (KIS) }\end{array}$ & $\begin{array}{r}\text { High-tech } \\
\text { KIS }\end{array}$ & Market KIS & $\begin{array}{r}\text { Less-knowledge- } \\
\text { intensive services } \\
\text { (LKIS) }\end{array}$ & $\begin{array}{r}\text { Market } \\
\text { LKIS }\end{array}$ \\
\hline Majority foreign & $\begin{array}{l}-0.081^{* * * *} \\
(0.005)\end{array}$ & $\begin{array}{l}-0.089^{* * * *} \\
(0.011)\end{array}$ & $\begin{array}{l}-0.071^{* * * *} \\
(0.006)\end{array}$ & $\begin{array}{l}-0.045^{* * * *} \\
(0.004)\end{array}$ & $\begin{array}{c}-0.039^{* * * *} \\
(0.004)\end{array}$ \\
\hline Majority domestic & $\begin{array}{l}0.024^{* * * *} \\
(0.006)\end{array}$ & $\begin{array}{c}0.007 \\
(0.013)\end{array}$ & $\begin{array}{l}0.020^{* * *} \\
(0.008)\end{array}$ & $\begin{array}{l}0.026^{* * * *} \\
(0.004)\end{array}$ & $\begin{array}{l}0.026^{* * *} \\
(0.004)\end{array}$ \\
\hline Majority unknown & $\begin{array}{r}-0.009 \\
(0.006)\end{array}$ & $\begin{array}{c}-0.047^{* * * *} \\
(0.014)\end{array}$ & $\begin{array}{l}-0.006 \\
(0.007)\end{array}$ & $\begin{array}{c}-0.011^{\text {***** }} \\
(0.004)\end{array}$ & $\begin{array}{c}-0.011^{* * * *} \\
(0.004)\end{array}$ \\
\hline $\begin{array}{l}\text { Monitored majority } \\
\text { foreign }\end{array}$ & $\begin{array}{l}-0.069^{* *} \\
(0.027)\end{array}$ & $\begin{array}{l}-0.054 \\
(0.038)\end{array}$ & $\begin{array}{l}-0.086^{* *} \\
(0.038)\end{array}$ & $\begin{array}{l}-0.047^{* *} \\
(0.020)\end{array}$ & $\begin{array}{l}-0.024 \\
(0.019)\end{array}$ \\
\hline $\begin{array}{l}\text { Monitored majority } \\
\text { domestic }\end{array}$ & $\begin{array}{c}-0.041^{* * *} \\
(0.008)\end{array}$ & $\begin{array}{c}-0.083^{* * *} \\
(0.018)\end{array}$ & $\begin{array}{c}-0.034^{* * *} \\
(0.010)\end{array}$ & $\begin{array}{l}0.026^{* * * *} \\
(0.006)\end{array}$ & $\begin{array}{l}0.029^{* * *} \\
(0.006)\end{array}$ \\
\hline $\begin{array}{l}\text { Monitored majority } \\
\text { unknown }\end{array}$ & $\begin{array}{l}0.051^{* * *} \\
(0.011)\end{array}$ & $\begin{array}{c}0.017 \\
(0.026)\end{array}$ & $\begin{array}{l}0.055^{* * *} \\
(0.013)\end{array}$ & $\begin{array}{l}-0.004 \\
(0.007)\end{array}$ & $\begin{array}{l}-0.007 \\
(0.007)\end{array}$ \\
\hline $\begin{array}{l}\text { Controlling minority } \\
\text { foreign }\end{array}$ & $\begin{array}{l}-0.008 \\
(0.013)\end{array}$ & $\begin{array}{c}0.006 \\
(0.028)\end{array}$ & 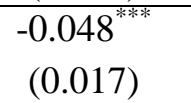 & $\begin{array}{l}-0.012 \\
(0.009)\end{array}$ & $\begin{array}{l}0.002 \\
(0.009)\end{array}$ \\
\hline $\begin{array}{l}\text { Controlling minority } \\
\text { domestic }\end{array}$ & $\begin{array}{c}-0.101^{* * *} \\
(0.008)\end{array}$ & $\begin{array}{l}-0.143^{* * *} \\
(0.019) \\
\end{array}$ & $\begin{array}{c}-0.095^{* * *} \\
(0.009)\end{array}$ & $\begin{array}{l}-0.087^{* * *} \\
(0.006)\end{array}$ & $\begin{array}{c}-0.084^{* * *} \\
(0.006) \\
\end{array}$ \\
\hline $\begin{array}{l}\text { Combined controlling } \\
\text { minority foreign }\end{array}$ & $\begin{array}{l}-0.137^{* * * * *} \\
(0.025)\end{array}$ & $\begin{array}{l}-0.070 \\
(0.060)\end{array}$ & $\begin{array}{l}-0.158^{\text {***** }} \\
(0.029)\end{array}$ & $\begin{array}{l}0.087^{* * * *} \\
(0.018)\end{array}$ & 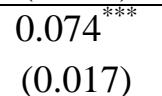 \\
\hline $\begin{array}{l}\text { Combined controlling } \\
\text { minority domestic }\end{array}$ & $\begin{array}{c}-0.032^{* * * *} \\
(0.006)\end{array}$ & $\begin{array}{l}-0.047^{* * *} \\
(0.012)\end{array}$ & $\begin{array}{l}-0.035^{* * *} \\
(0.008)\end{array}$ & $\begin{array}{l}-0.004 \\
(0.004)\end{array}$ & $\begin{array}{l}-0.002 \\
(0.004)\end{array}$ \\
\hline $\log ($ Total assets $)$ & $\begin{array}{l}0.059^{* * * *} \\
(0.001)\end{array}$ & $\begin{array}{c}0.056^{* * *} \\
(0.002)\end{array}$ & $\begin{array}{l}0.060^{* * * *} \\
(0.001)\end{array}$ & $\begin{array}{l}0.062^{* * * *} \\
(0.000)\end{array}$ & $\begin{array}{c}0.062^{* * *} \\
(0.000)\end{array}$ \\
\hline Debt $\mathrm{r}$ & $\begin{array}{l}0.003^{* * * *} \\
(0.000)\end{array}$ & $\begin{array}{c}0.017^{* * *} \\
(0.002)\end{array}$ & $\begin{array}{l}0.003^{* * * *} \\
(0.000)\end{array}$ & $\begin{array}{l}0.002^{* * * * *} \\
(0.000)\end{array}$ & $\begin{array}{c}0.001^{* * *} \\
(0.000)\end{array}$ \\
\hline Age of the firm & $\begin{array}{l}-0.007^{* * *} \\
-0.420^{* * *}\end{array}$ & $\begin{array}{c}-0.001^{*} \\
-0.420^{* * * *}\end{array}$ & $\begin{array}{l}-0.008^{* * *} \\
-0.434^{* * *}\end{array}$ & $\begin{array}{l}-0.005^{* * * *} \\
-0.483^{* * *}\end{array}$ & $\begin{array}{l}-0.005^{* * *} \\
-0.480^{* * *}\end{array}$ \\
\hline Constant & $\begin{array}{l}(0.007) \\
(0.000) \\
\end{array}$ & $\begin{array}{l}(0.020) \\
(0.001) \\
\end{array}$ & $\begin{array}{l}(0.008) \\
(0.000)\end{array}$ & $\begin{array}{l}(0.005) \\
(0.000) \\
\end{array}$ & $\begin{array}{l}(0.005) \\
(0.000) \\
\end{array}$ \\
\hline R squared & 0.237 & 0.231 & 0.239 & 0.244 & 0.247 \\
\hline $\mathrm{N}$ & 39670 & 5327 & 30085 & 81496 & 81067 \\
\hline
\end{tabular}

Note: ${ }^{* * *},{ }^{* *}$, and ${ }^{*}$ denote significance at the $1 \%, 5 \%$, and $10 \%$ levels, respectively. 
Figure 1: Ownership effects - Distance from efficiency frontier
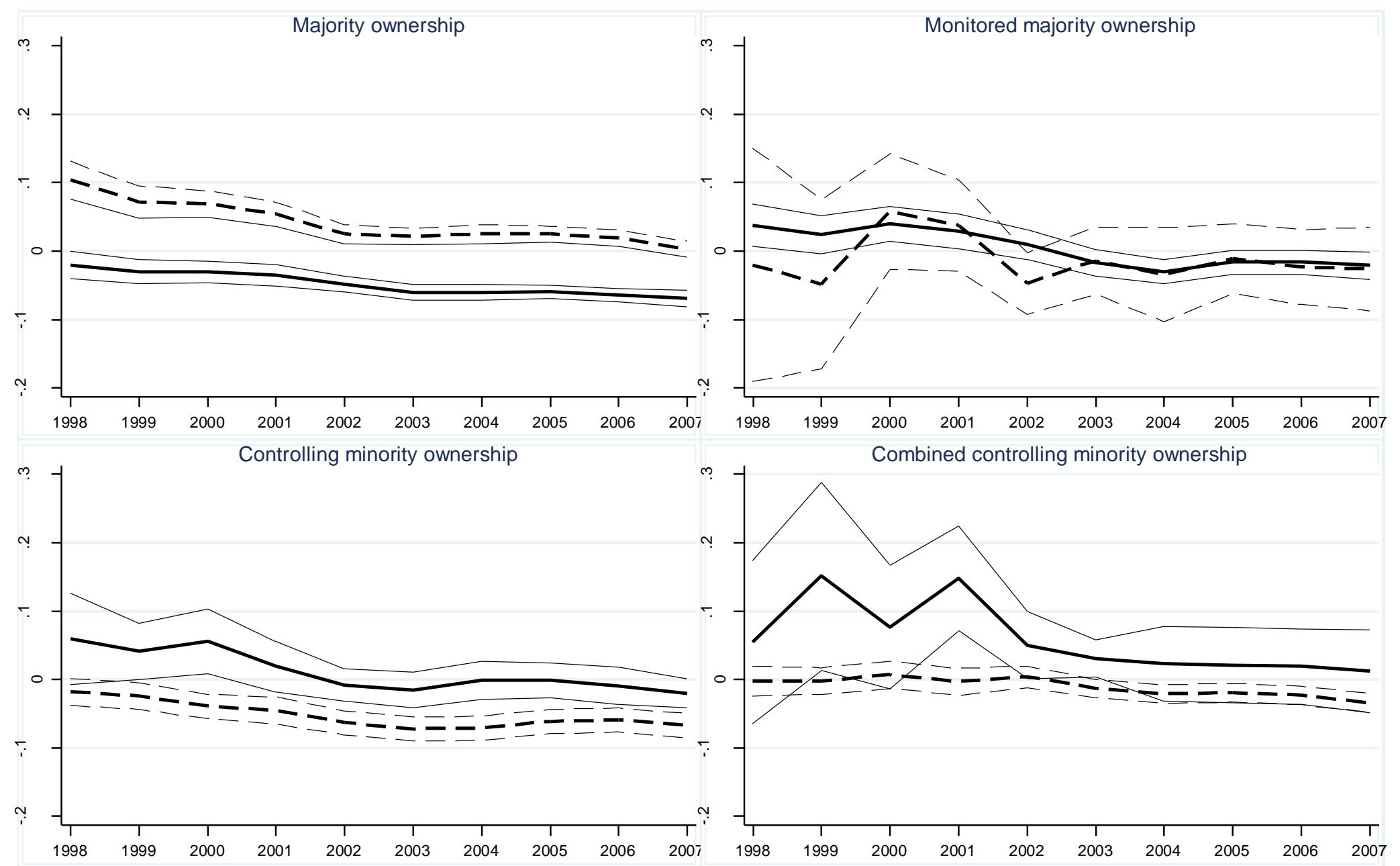

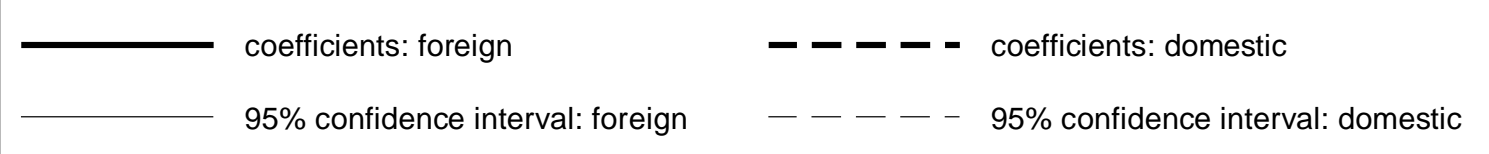




\section{Working Paper Series}

ISSN 1211-3298

Registration No. (Ministry of Culture): E 19443

Individual researchers, as well as the on-line and printed versions of the CERGE-EI Working Papers (including their dissemination) were supported from the following institutional grants:

- Economic Aspects of EU and EMU Entry [Ekonomické aspekty vstupu do Evropské unie a Evropské měnové unie], No. AVOZ70850503, (2005-2011);

- Economic Impact of European Integration on the Czech Republic [Ekonomické dopady evropské integrace na ČR], No. MSM0021620846, (2005-2011);

Specific research support and/or other grants the researchers/publications benefited from are acknowledged at the beginning of the Paper.

(c) Jan Hanousek, Evžen Kočenda, and Michal Mašika, 2012

All rights reserved. No part of this publication may be reproduced, stored in a retrieval system or transmitted in any form or by any means, electronic, mechanical or photocopying, recording, or otherwise without the prior permission of the publisher.

Published by

Charles University in Prague, Center for Economic Research and Graduate Education (CERGE) and

Economics Institute ASCR, v. v. i. (EI)

CERGE-El, Politických vězňů 7, 11121 Prague 1, tel.: +420 224005 153, Czech Republic.

Printed by CERGE-EI, Prague

Subscription: CERGE-EI homepage: http://www.cerge-ei.cz

Phone: + 420224005153

Email: office@cerge-ei.cz

Web: http://www.cerge-ei.cz

Editor: Michal Kejak

Editorial board: Jan Kmenta, Randall Filer, Petr Zemčík

The paper is available online at http://www.cerge-ei.cz/publications/working_papers/.

ISBN 978-80-7343-259-1 (Univerzita Karlova. Centrum pro ekonomický výzkum a doktorské studium)

ISBN 978-80-7344-251-4 (Národohospodářský ústav AV ČR, v. v. i.) 
CERGE-EI

P.O.BOX 882

Politických vězňů 7

11121 Praha 1

Czech Republic http://www.cerge-ei.cz 